\title{
Monitoring of Hard Ticks at Urban Recreational Sites in the City of Zagreb from 2016 to 2018
}

\author{
Praćenje tvrdih krpelja u urbanim rekreacijskim odredištima grada Zagreba \\ od 2016. do 2018. godine
}

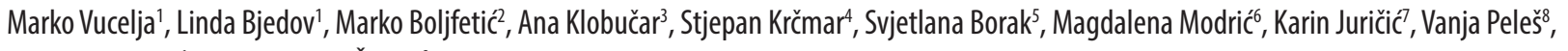
Josip Margaletić' ${ }^{1}$ Tatjana Vilibić Čavlek ${ }^{9}$

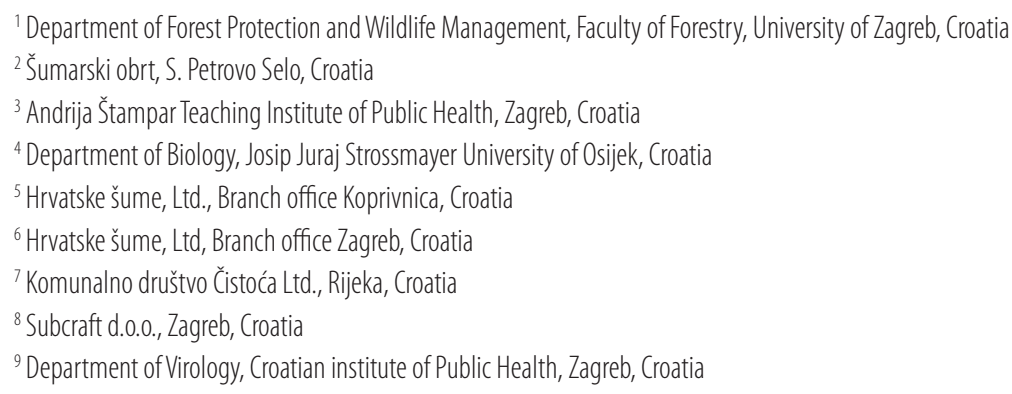

Keywords:
hard ticks
Zagreb
Croatia
Ixodes ricinus
monitoring

Ključne riječi:
tvrdi krpelji
Zagreb
Hrvatska
Ixodes ricinus
praćenje

Primljeno: 17.2.2019.

Received: 17.2.2019.

Prihvaćeno: 18.3 .2019

Accepted: 18.3.2019.

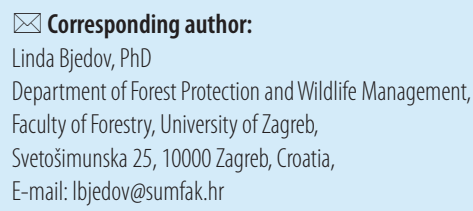

\begin{abstract}
As tick-borne disease incidence and distribution is increasing worldwide, there is a true need for better understanding of the distributional ecology of their vectors. The aim of this study was to determine the diversity of hard ticks fauna (Acari: Ixodidae) and their seasonal dynamics in different habitats at three urban recreational sites in Croatia's capital, the City of Zagreb, known as the natural foci of Lyme borreliosis and tick borne encephalitis. Within a three-year period (2016 - 2018), the only species detected was Ixodes ricinus Linnaeus, 1758. Using flag dragging method 506 ticks were sampled; 273 (54\%) in their nymphal stage, 166 (33\%) as larvae and 64 (13\%) as adults. The highest abundance of ticks was recorded at forest habitat. Seasonal activity showed their peaks at midspring and midsummer. Continuous monitoring of hard tick population in urban areas should and could become a standard method of tick-borne diseases prevention.
\end{abstract}

Sažetak

Kako se učestalost i rasprostranjenost krpeljnih bolesti širom svijeta povećava, postoji stvarna potreba za boljim razumijevanjem distribucijske ekologije njihovih vektora. Cilj ovog istraživanja bio je odrediti raznolikost faune tvrdih krpelja (Acari: Ixodidae) i njihovu sezonsku dinamiku na različitim staništima u tri urbana rekreacijska odredišta u glavnom gradu Hrvatske, Zagrebu, poznatom kao prirodnom žarištu lajmske borelioze i krpeljnog meningoencefalitisa. Tijekom trogodišnjeg razdoblja (2016. - 2018. god.) jedina determinirana vrsta bila je Ixodes ricinus Linnaeus, 1758. Metodom krpeljne zatege, prikupljeno je 506 jedinki tvrdih krpelja, od čega 273 (54\%) u razvojnom stadiju nimfe, 166 (33\%) u stadiju ličinke i 64 (13\%) u odraslom stadiju. Najveći broj krpelja sakupljen je u šumskom staništu. Sezonska aktivnost krpelja dosezala je maksimume sredinom proljeća i sredinom ljeta. Kontinuirano praćenje populacije tvrdih krpelja u urbanim područjima trebalo bi, i moglo bi, postati standardna metoda prevencije bolesti koje prenose krpelji. 


\section{Introduction}

Hard ticks (Acari: Ixodidae) are one of the main arthropod-borne disease vectors in Europe and also worldwide. Due to the recent predictions of their expansion, which includes the increasing incidence and distribution of tick-borne diseases in correlation to climate change, they manage to attain more of public attention $^{[1-3]}$. Infesting a wide variety of wild vertebrate species, but also livestock, companion animals and humans, these obligatory hematophagous ectoparasites transmit numerous infectious agents (virus, bacteria, protozoa $)^{[4,5]}$ causing the spread of various diseases like Lyme borreliosis (LB), tick-borne encephalitis (TBE), tularaemia, Mediterranean spotted fever, human granulocytic anaplasmosis etc. ${ }^{[6-9]}$. From the first studies on the occurrence of ixodid species in Croatia, about 80 years ago, till today, around 22 tick species, belonging to five genera (Ixodes, Haemaphysalis, Rhipicephalus, Dermacentor, Hyalomma) were recorded, and the most abundant and widespread species is the Ixodes ricinus (Castor bean tick, Sheep tick, Deer tick, Forest tick ${ }^{[10,11]}$. Ixodes ricinus plays an important role in spreading LB and TBE in Croatian inland ${ }^{[12-19]}$, especially in the northern and northwestern part where high prevalence (40 - 90\%) of Borrelia burgdorferi within tick population has been recorded ${ }^{[13,20,21]}$. Tickborne diseases are characterized by seasonal occurrence with the highest rate of infection in the summer months ${ }^{[16]}$ which is in correlation with tick's preferring warm and humid environmental conditions ${ }^{[22]}$. Being limited by temperature and humidity and also with the distribution of their hosts, ticks inhabit deciduous and mixed forests as a typical microhabitat (providing leaf litter that maintains high relative humidity), but also coniferous forests, grasslands, pastures some urban, peri-urban, and recreational environments with matching microclimate and enough host population $^{[23-30]}$. The city of Zagreb, as Croatia's capital inhabited by nearly the forth of Croatian's population, has been known as natural foci of LB and TBE and also for high prevalence of $B$. burgdorferi within the tick population ${ }^{[13,16]}$. Since ticks have specific preferences to- wards their microhabitat, being aware of the hotspots they inhabit while seeking for the next host, may help prevent the diseases. The aim of this study was to establish the structure and population dynamics of hard ticks in different habitats at three popular recreational urban sites in the City of Zagreb in period from 2016 to 2018 .

\section{Methods}

This study was carried out at three recreational urban sites in Croatia's capital, the City of Zagreb, that is located in the northwest of the country, at the southern slopes of the mountain Medvednica along the Sava river (122 $\mathrm{m}$ above sea level). The first urban site was in the oldest public park in Zagreb; Park Maksimir (316 ha, $120-167 \mathrm{~m}$ above sea level, $11^{\circ} \mathrm{C}$ mean annual temp., annual precipitation $870 \mathrm{~mm}$ ), located in the eastern central part of the city, with forest association of common oak (Quercus robur) and hornbeam (Carpinus betulus) (Carpino betuli - Quercetum roboris /Anić 1959/Rauš 1969) in southern lowland parts, and association of Sessile oak (Quercus petraea) and horn beam (Epimedio - Carpinetum betuli / Ht. 1938 / Borh. 1963) and also with Sweet chestnut (Castanea sativa) at elevated terrains (Querco - Castanetum sativae Horvat 1938). In Park Maksimir, besides forests, there are meadows, lakes and streams. The second urban site was recreational and sports centre (RSC) Jarun (240 ha), located in the southwestern part of Zagreb, on the northern banks of river Sava, with two lakes, six islands, meadows and groves with dominant autochthonous willow and poplar vegetation. The third urban site was RSC Bundek (55 ha) located in the southern part of the city, on the southern banks of river Sava, with two lakes, meadows and groves with dominant autochthonous willow and poplar vegetation. Ticks were sampled in all three parks at different habitats, which were chosen according to park landscape. This resulted in some overlapping as well as different habitats (Table 1.). At Park Maksimir ticks were sampled during years 2016, 2017 and 2018, and at RSC Jarun and RSC Bundek during 2017 and 2018.

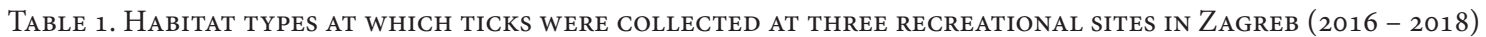

\begin{tabular}{|c|c|c|c|c|}
\hline Locality & \multicolumn{2}{|c|}{ Habitat } \\
\hline $\begin{array}{c}\text { Park Maksimir } \\
(2016-2018)\end{array}$ & Forest & Forest edge & Meadow & Forest trail \\
\hline $\begin{array}{c}\text { RSC Jarun } \\
(2017-2018)\end{array}$ & Forest & Forest edge & Meadow & Trail by the lake \\
\hline $\begin{array}{c}\text { RSC Bundek } \\
(2017-2018)\end{array}$ & Forest & Pond edge & Meadow area & River embankment \\
\hline
\end{tabular}


Tick were sampled by flag dragging method ${ }^{[31-33]}$, using white flannel cloth $(1 \mathrm{~m} \times 1 \mathrm{~m})$. Sampling was done once a month, from spring till autumn. Transects were of $50 \mathrm{~m}$ in length and sampling was done in 30 -minute periods. Identification of ticks was done using standard keys for European ticks ${ }^{[34]}$ via stereomicroscope (Olympus Leica Wild m28).

\section{Results}

From 2016 to 2018, 506 ticks were sampled at three popular recreational sites in Zagreb; 326 (65\%) in Park Maksimir, 173 (34\%) at RSC Jarun and seven (1\%) at RSC Bundek. All sampled specimens were morphologically identified as Ixodes ricinus Linnaeus, 1758 (Wood tick, Deer tick, Sheep tick, Forest tick, Castor bean tick). At Park Maksimir ticks were sampled 22 times $(7 / 2016,9 / 2017,6 / 2018)$, at RSC Jarun 17 times (9/2017, 8/2018) and at RSC Bundek 13 times (8/2017, $5 / 2018$ ). The highest number of sampled ticks were in nymphalid stage (276; 54\%), $166(33 \%)$ were in larval stage and $64(28$ त, 36 \%) (13\%) were adults. Table 2. shows the number of collected ticks in their developmental stages collected at different sampling sites.

The highest number of ticks in Park Maksimir $(\mathrm{N}=237 ; 73 \%)$ and also at RSC Jarun $(\mathrm{N}=114 ; 66 \%)$ were sampled at forest habitat (Table 3.), while at RSC Bundek it was habitat river embankment $(\mathrm{N}=4 ; 57 \%)$ that showed the highest abundance of ticks (Table 3.). In total, for all three recreational sites, the highest tick abundance was recorded at forest habitats, $(\mathrm{N}=352$; $69.6 \%$ ), following forest edge habitat with 106 ticks (20.9\%) (Table 3.), while other habitats had tick abundance under $3.2 \%$.

From a total of 506 tick specimens sampled most were nymphs covering $54.5 \%(\mathrm{~N}=276)$ of all catch (Figure 1.). Tick larvae made $32.8 \%(\mathrm{~N}=166)$ and adults made $12.6 \%(\mathrm{~N}=64)$ of all catch. Similar ratio of adults, nymphs and larvae was found within Park Maksimir and RSC Jarun (Figure 1.).

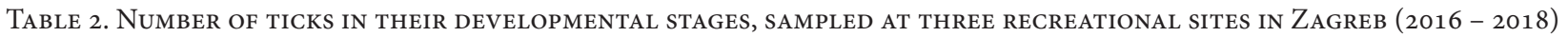

\begin{tabular}{|c|c|c|c|c|}
\hline Locality & IR L & IR N & IR A [ð̋/†] & $\Sigma$ \\
\hline $\begin{array}{l}\text { Park Maksimir } \\
(2016-2018)\end{array}$ & 113 & 176 & $37[12 / 25]$ & 326 \\
\hline $\begin{array}{l}\text { RSC Jarun } \\
(2017-2018)\end{array}$ & 53 & 95 & $25[14 / 11]$ & 173 \\
\hline $\begin{array}{l}\text { RSC Bundek } \\
(2017-2018)\end{array}$ & 0 & 5 & $2[2 / 0]$ & 7 \\
\hline$\Sigma$ & 166 & 276 & $64[28 / 36]$ & 506 \\
\hline
\end{tabular}

(IR=Ixodes ricinus Linnaeus, 1758; A=adult; $\widehat{O}$ : adult male; : : adult female; $\mathrm{N}=$ nymph; $\mathrm{L}=$ larva)

Table 3. Abundance of Sampled ticks (Ixodes Ricinus Linnaeus, 1758) at Five Different habitats at three Recreational SITES IN ZAGREB (2016 - 2018)

\begin{tabular}{|c|c|c|c|c|}
\hline Habitat & $\begin{array}{c}\text { Park Maksimir } \\
(2016-2018\end{array}$ & $\begin{array}{c}\text { RSC Jarun } \\
(2017-2018)\end{array}$ & $\begin{array}{c}\text { RSC Bundek } \\
(2017-2018)\end{array}$ \\
\hline Forest & 237 & 114 & 1 & $\mathbf{3 5 2}$ \\
\hline Forest edge & 55 & 51 & - & $\mathbf{1 0 6}$ \\
\hline Forest trail & 16 & - & - & $\mathbf{1 6}$ \\
\hline Meadow & 12 & 3 & - & $\mathbf{6}$ \\
\hline Lake embankment & 6 & - & 0 & $\mathbf{1}$ \\
\hline Park area & - & 1 & - & $\mathbf{4}$ \\
\hline Trail by the lake & - & 4 & 4 & $\mathbf{4}$ \\
\hline River embankment & - & - & 2 & $\mathbf{2}$ \\
\hline Pond edge & $\mathbf{3 2 6}$ & $\mathbf{1 7 3}$ & $\mathbf{7}$ \\
\hline $\mathbf{\Sigma}$ & & & 5 \\
\hline
\end{tabular}


Figure 1. DifFERENT LIFE STAgES OF SAMPLED TICKS AT THREE RECREATIONAL SITES IN ZAGREB (2016 - 2018)

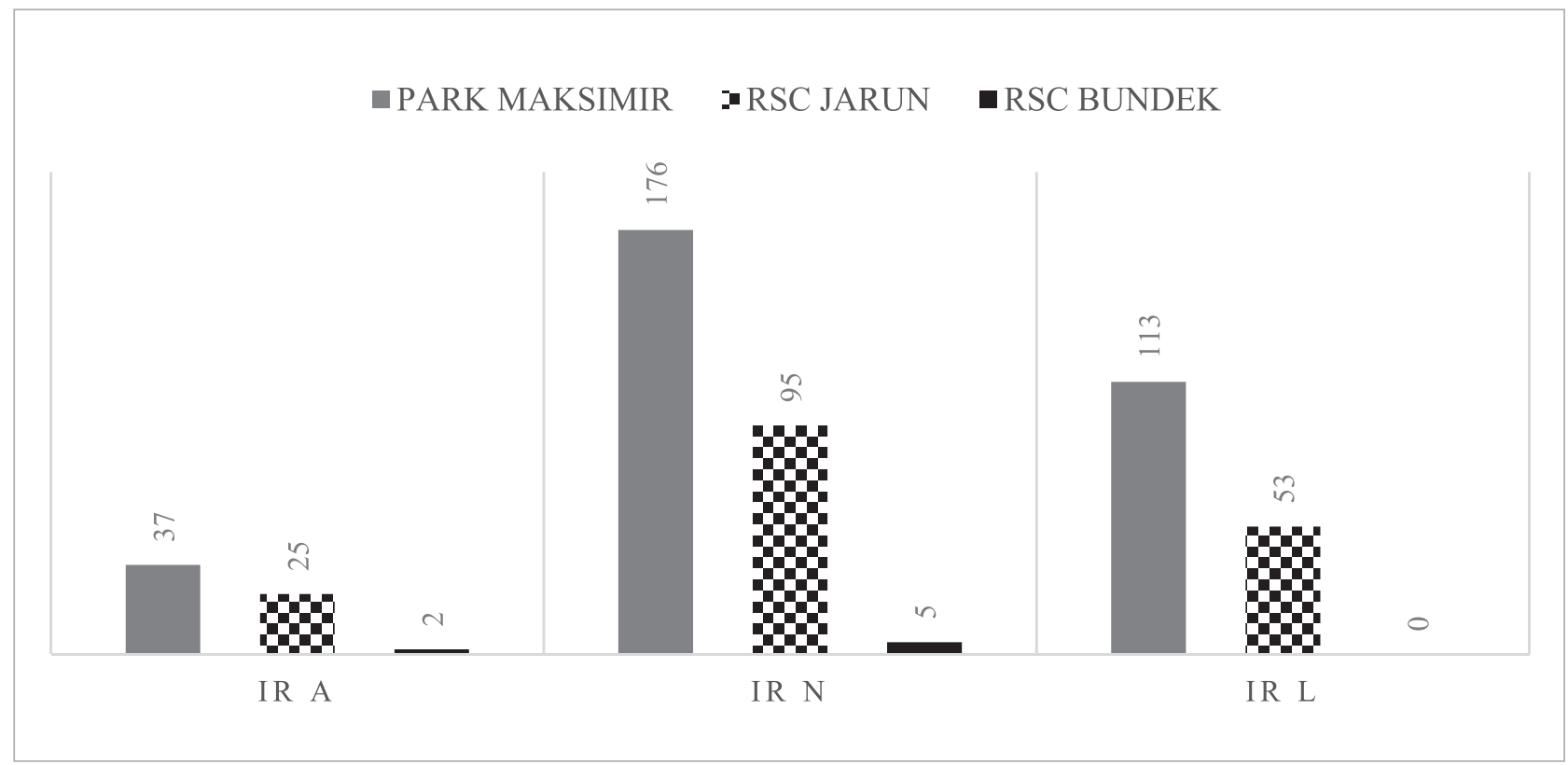

( $\mathrm{IR}=$ Ixodes ricinus Linnaeus, 1758; $\mathrm{A}=$ adult; $\mathrm{N}=$ nymph; $\mathrm{L}=$ larva)

Data of seasonal tick dynamics combined for all three recreational sites showed distinctive peaks in May for nymphs during all three years (Figure 2.). Adult ticks were collected in much smaller numbers in compari- son to nymphs but were also most abundant in May or June (Figure 2.). Larvae were collected only in the summer of 2018 peaking in August with highest abundance in comparison to adults and nymphs (Figure 2.).

Figure 2. RELATIVE MONTHLY TICK (IXODES RICINUS LiNNAEUS, 1758) ABUNDANCE FOR THREE LIFE STAGES AT ALL RECREATIONAL SITES IN ZAGREB (2016 - 2018)

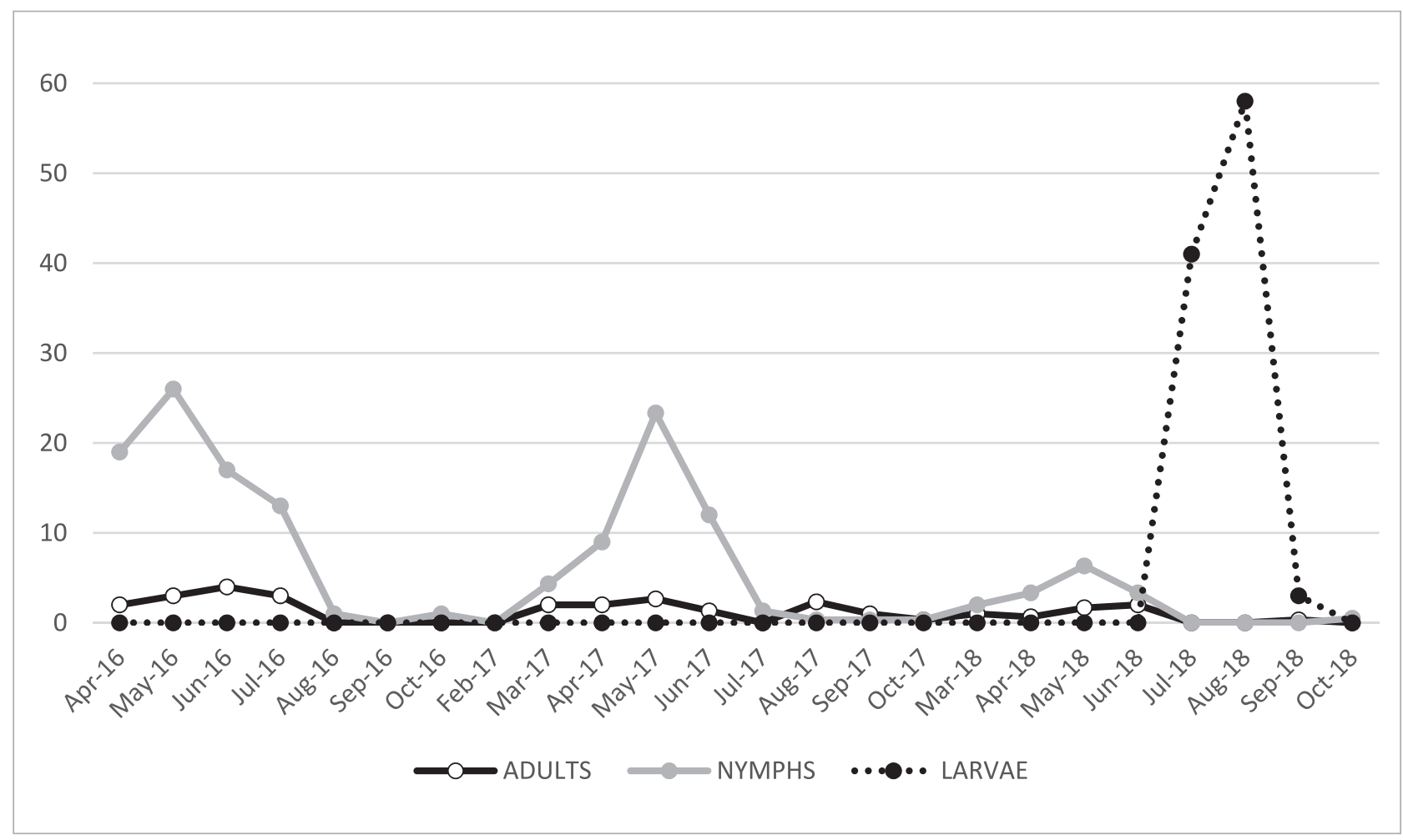




\section{Discussion and Conclusion}

Most of the comprehensive studies on tick fauna in Croatia has been done from the 1950s till 1980s and the emphasis of those studies were on the distribution, dynamics and the diversity of tick fauna along the Adriatic coast and on the islands in the Adriatic Sea ${ }^{[10]}$. While collecting the data regarding the occurrence of ixodid species in Croatia, Krčmar (2012) $)^{[10]}$ counted 79 sampling sites (only 16 in inland!) and also contributed with several new localities, mainly at eastern part of the country ${ }^{[35]}$. Considering that the City of Zagreb is known as a natural focus of Lyme borreliosis and tick-borne encephalitis ${ }^{[13,20,21]}$, there is not much information about species distribution, abundance or seasonal dynamics of hard ticks in the Croatia's capital. From 1959 till 1975 in Zagreb and its vicinity, only three species from genus Ixodes were recorded (Ixodes ricinus Linnaeus, 1758; Ixodes arboricola Schulze \& Schlottke 1930; Ixodes frontalis Panzer, 1798) ${ }^{[36-38]}$ and the list was expanded in 2008 with one species from genus Dermacentor (D. reticulatus Fabricius, 1794) ${ }^{[13]}$. In this study, Ixodes ricinus was the only species of hard ticks collected at three popular urban recreational sites in Zagreb. These results agree with previous findings of Ixodes ricinus being the most widely distributed species in continental part of Croatia, as it is in Europe ${ }^{[10,39]}$, but also indicates a little diversity of tick fauna in the City of Zagreb. Through our research no Dermacentor reticulatus was found, although it has been previously sampled, using the same sampling methods, at RSC Jarun in $2008^{[13]}$. Except the slow natural succession of forest habitat, no major changes in the environment, nor the vegetation management, or the presence of potential hosts, took place at RSC Jarun since 2008, to our knowledge. Including more micro localities in future monitoring of ticks at RCS Jarun could provide some answers. Our work is in line with the general trend of collecting Ixodes ricinus more frequently than the other species during field sampling ${ }^{[40]}$. In every locality included in this study, most ticks were collected in their immature and more abundant, nymphal stage, in which they, being physically smaller and harder to notice, pose a bigger threat to humans regarding transmission of different pathogens (Table 2. ${ }^{[41]}$. In Park Maksimir and in RSC Jarun, the habitat with the highest abundance of ticks, in all developmental stages, was the forest type habitat and that matches tick's microclimate preferences (Table 3.) $[23-26,42]$. The second habitat with the highest number of sampled ticks was the forest edge. Ninety percent of sampled ticks in Park Maksimir and 95\% at RSC Jarun were collected in forest and forest edge, indicating that the suitability of habitats for Ixodes ricinus is highly influenced by forest cover in urban areas providing ticks with adequate microclimate and reproductive hosts (27-30). Comparing all three localities included in this research Park Maksimir, although not inhabited anymore by large herbivorous, like European roe deer (Capreolus capreolus), red deer (Cervus elaphus) and even carnivores like grey wolf (Canis lupus), still provides a home for largest number of animal species (e.g. red squirrel; Sciurus vulgaris, edible dormouse; Glis glis, marten; Martes ssp., red fox; Vulpes and over 100 bird species) that make potential ticks hosts. Another thing that makes Park Maksimir a suitable habitat for stable tick populations is its' sessile oak forest communities with ferns (Pteridium aquilinum) in under tree cover $^{[34]}$. At RSC Bundek only seven specimens of ticks were collected during two-year period and all three habitats on which they were collected included tree coverage to some extent (Table 3.). The main reasons for such a small number of ticks at RSC Bundek is, most presumably very good vegetation management (mowing once a week) along with an absence of tick's natural hosts, while Bundek, as a recreational site is in highly urban area (43) surrounded by heavy traffic roads and residential buildings. Unfortunately, there is a lack of information about small rodent populations at these three sites, while no continuous monitoring is being conducted. Seasonal dynamics of sampled ticks at Park Maksimir showed typical peak during spring time, in May, which corresponds to previous findings ${ }^{[44]}$, but it also reached its second peak in the mid-summer, in August, which is a bit earlier than is usually expected ${ }^{[42]}$. At RSC Jarun, the peaks were recorded in May 2017 and in July 2018. At RSC Bundek the autumn peak was recorded in October 2017 and according to Estrada-Peńa et al. ${ }^{[34]}$ that corresponds to activity of adult ticks. In Park Maksimir and RSC Jarun, ticks in their nymphalid stage, were most abundant in May, while as larvae they were sampled only in the midsummer of 2018 (Figure 3.) which corresponds to different field studies ${ }^{[34]}$ and also the results of recent study in the surroundings of city Beli Manastir, in eastern Croatia ${ }^{[35]}$. At all three localities ticks in their adult stage were collected till midsummer in July, when they are usually affected by diapause ${ }^{[40]}$. Seasonal dynamics at different habitats (Table 3.) indicates that in opened habitats which are more exposed to direct sunlight (like meadows), ticks will appear from early spring till early summer and then again at the beginning of autumn, and in forest habitats they'll find convenient temperature and humidity conditions even in midsummer ${ }^{[45]}$. We have collected specimens of Ixodes ricinus in all three life stages and it matches a fact that all stages of this species climb on vegetation in search for a 
host $^{[34]}$. Despite extremely warm thermal conditions in the City of Zagreb in 2016, 2017 and 2018 ${ }^{[46]}$, the number of sampled ticks was increasing through the years in Park Maksimir and at RSC Jarun and it is in line with Ixodes ricinus being less sensitive on temperature changes ${ }^{[47]}$ than the other tick species. Stability of the population was presumably aided by the annual precipitation $^{[40,48,49]}$, that was in line with multi-annual average during this three-year period ${ }^{[47]}$. There are already many indications that climate change will back up the expansion of ixodid ticks ${ }^{[50,51]}$ and it will also include the increasing incidence and distribution of tick-borne diseases ${ }^{[1-3,45,52]}$. While Ixodes ricinus, with its ecological plasticity and ability to adapt, will continue to pose a threat to human health ${ }^{[53-55]}$, the continuous monitoring, detection and reporting of its population, and also of the population of its main hosts, would surely help to improve public health standards by means of prevention.

\section{Acknowledgment}

Collection of ticks during 2018 was supported by the project: HRZZ IP 2016-06-7456: Prevalence and molecular epidemiology of emerging and re-emerging neuro-invasive arboviral infections in Croatia; CRONEUROARBO (to TVC).

\section{REFERENCES}

${ }^{[1]}$ Stone BL, Tourand Y, Brissette C. Brave New Worlds: The Expanding Universe of Lyme Disease. Vector Borne Zoonotic Dis. 2017;17:619-629.

${ }^{[2]}$ Alkishe AA, Peterson AT, Samy AM. Climate change influences on the potential geographic distribution of the disease vector tick Ixodes ricinus. PLoS One. 2017;12:e0189092.

${ }^{[3]}$ Lindgren E, Tällekint L, Polfeldt T. Impact of climatic change on the northern latitude limit and population density of the disease-transmitting European tick Ixodes ricinus. Environ Health Perspect. 2000; 108: 119-123.

${ }^{[4]}$ Hornok S, Farkas R. Influence of biotope on the distribution and peak activity of questing ixodid ticks in Hungary. Med. Vet. Entomol. 2009; 23: 41-46.

${ }^{[5]}$ Hubálek Z. Biogeography of Tick-Borne Bhanja Virus (Bunyaviridae) in Europe. Interdiscip Perspect Infect Dis. 2009; 2009:372691.

${ }^{[6]}$ Rauter C, Hartung T. Prevalence of Borrelia burgdorferi sensu lato genospecies in Ixodes ricinus ticks in Europe: a metaanalysis. Appl Environ Microbiol. 2005; 71(11):7203-16.

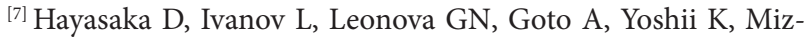
utani T, Kariwa H, Takashima I. Distribution and characterization of tick-borne encephalitis viruses from Siberia and far-eastern Asia. J Gen Virol. 2001; 82:1319-2.

${ }^{[8]}$ Stuen S. Anaplasma phagocytophilum-the most widespread tick-borne infection in animals in Europe. Vet Res Commun. 2007; 31(1): 79-84.
${ }^{[9]}$ Mihelčić M, Habuš J, Vucelja M, et al. Prevalence of Francisella tularensis in the population of small mammals species in continental forests of Croatia. Šumarski list, 2018; 9-10: 481-486

${ }^{[10]}$ Krčmar S. Hard ticks (Acari, Ixodidae) of Croatia. ZooKeys, 2012; 234: 19-57.

${ }^{[11]}$ Hornok S, Sándor AD, Beck R, et al. Contributions to the phylogeny of Ixodes (Pholeoixodes) canisuga, I. (Ph.) kaiseri, $I$. (Ph.) hexagonus and a simple pictorial key for the identification of their females. Parasit Vectors. 2017; 10: 545.

${ }^{[12]}$ Mulić R, Petković B, Klišmanić Z, Jerončić I. Bolesti koje se prenose krpeljima na području Hrvatske. Liječ Vjesn, 2011; 133:89-95.

${ }^{[13]}$ Barišin A, Nemeth Blažić T, Jeličić P, Gjenero Margan I, Capak K, Petrović G. Prikaz istraživanja krpelja na području Grada Zagreba u 2008. godini. Zbornik radova, DDD i ZUPP, 2011; 203-211.

${ }^{[14]}$ Vodopija R, Pahor Đ, Sušanj M. Krpelji od javno zdravstvene važnosti u Republici Hrvatskoj i mjere zaštite. Zbornik radova, DDD i ZUPP 2016, 2016; 2013 - 223.

${ }^{[15]}$ Markotić A, Cvetko Krajinović L, Margaletić J, et al. Zoonoses and vector-borne diseases in Croatia - a multidisciplinary approach. Vet Ital. 2009; 45(1): 55-66.

${ }^{[16]}$ Mulić R, Antonijević S, Klišmanić Z, Ropac D, Lučev O. Epidemiological Characteristics and Clinical Manifestations of Lyme Borreliosis in Croatia. Mil Med, 2006; 171 (11):1105.

${ }^{[17]}$ Golubić D, Hegedus-Jungvirth M, Golubić R. Lyme borreliosis in children in northwest Croatia. Paediatr croat. 2000; 44(4):151-155.

${ }^{[18]}$ Anić K, Soldo I, Perić L, Karner I, Barac B. Tick-borne encephalitis in eastern Croatia. Scand J Infect Dis. 1998; 30(5):509-512.

${ }^{[19]}$ Miletić-Medved M, Đaković Rode O, Cvetko Krajinović L, Markotić A. Krpeljni meningoencefalitis u hrvatskoj srednjoj Posavini: seroepidemiološko ispitivanje u šumskih radnika. Croat Med J. 2011; 31 (2): 87-94.

${ }^{[20]}$ Rijepkema S, Golubić D, Molkenboer M, Verbeek DE, Kruif $\mathrm{N}$, Schellekens JFP. Identification of four genomic groups of B. burgdorferi sensu lato in Ixodes ricinus ticks collected in a Lyme borreliosis endemic region on northern Croatia. Exp Appl Acarol. 1996; 20:25-30.

${ }^{[21]}$ Golubić D, Rijepkema S, Tkalec-Malkovec N, Ružić E. Epidemiologic, ecologic and clinical characteristics of Lyme borreliosis in Northwest Croatia. Acta Med Croat. 1998; 1:7-13.

${ }^{[22]}$ Knap N, Durmiši E, Saksida A, Korva M, Petrovec M, Avišić-Župan T. Influence of climatic factors on dynamics of questing $I x$ odes ricinus ticks in Slovenia. Vet Parasitol. 2009; 164: 275-281.

${ }^{[23]}$ Ostfeld RS, Brunner JL. Climate change and Ixodes tick-borne diseases of humans. Phil Trans R Soc B. 2015; 370: 20140051.

${ }^{[24]}$ Estrada-Peña A. Distribution, abundance, and habitat preferences of Ixodes ricinus (Acari: Ixodidae) in northern Spain. J Med Entomol. 2001; 38:361-370.

${ }^{[25]}$ Walker AR, Alberdi MP, Urquhart KA, Rose H. Risk factors in habitats of the tick Ixodes ricinus influencing human exposure to Ehrlichia phagocytophila bacteria. Med Vet Entomol. 2001; 15:40-49. 


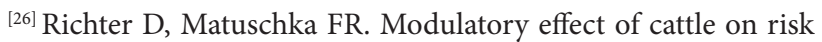
for lyme disease. Emerg Infect Dis. 2006; 12:1919-1923.

${ }^{[27]}$ Millins C, Gilbert L, Johnson P, et al. Heterogeneity in the abundance and distribution of Ixodes ricinus and Borrelia burgdorferi (sensu lato) in Scotland: Implications for risk prediction. Parasit Vectors. 2016; 9:595.

${ }^{[28]}$ Rizzoli A, Silaghi C, Obiegala A, et al. Ixodes ricinus and its transmitted pathogens in urban and peri-urban areas in Europe: New hazards and relevance for public health. Front Public Health. 2014; 2:251.

${ }^{[29]}$ Mackenstedt U, Jenkins D, Romig T. The role of wildlife in the transmission of parasitic zoonoses in peri-urban and urban areas. Int J Parasitol Parasites Wildl. 2015; 4 (1):71-79.

${ }^{[30]}$ Hansford KM, Fonville M, Gillingham EL, et al. Ticks and Borrelia in urban and peri-urban green space habitats in a city in southern England. Ticks Tick Borne Dis. 2017; 8:353-361.

${ }^{[31]}$ Cohnstaedt LW, Rochon K, Duehl AJ, et al. Arthropod Surveillance Programs: Basic Components, Strategies, and Analysis. Ann Entomol Soc Am. 2012; 105:135-149.

${ }^{[32]}$ Falco R., Fish D. The comparison of methods for sampling the deer tick, Ixodes dammini, in a Lyme disease endemic area. Exp Appl Acarol. 1992; 14: 165-173.

${ }^{[33]}$ Carroll JF, Schmidtmann ET. Tick sweep: modification of the tick drag - flag method for sampling nymphs of the deer tick (Acari: Ixodidae). J Med Entomol. 1992; 29 (2): 352-5.

${ }^{[34]}$ Estrada-Peña A, Bouattour A, Camicas JL, Walker AR. Ticks of Domestic Animals in the Mediterranean Region - A Guide to Identification of Species. University of Zaragoza: Atalanta, Houten, The Netherlands, 2004.

${ }^{[35]}$ Krčmar S, Vereš M, Trilar T. Fauna of hard ticks (Acari: Ixodidae) in different habitats in Croatian part of Baranja. Šumarski list, 2014; 5-6: 309-314.

${ }^{[36]}$ Tovornik D. On the bionomics of the Ixodes (Pholeoixodes) hexagonus Leach, 1815 in Slovenia (Yugoslavia). Biološki vestnik, 1987; 35: 101-120.

${ }^{[37]}$ Tovornik D. The significance of the birds (Aves) as the host and disseminators of ixodid ticks (Yugoslavia). Biološki vestnik, 1990; 38: 77-108.

${ }^{[38]}$ Tovornik D. Data on ticks Ixodes frontalis (Panzer, 1798) and Ixodes arboricola Schulze et Schlottke, 1929, found on birds in Yugoslavia. Biološki vestnik, 1991; 39: 157-164.

${ }^{[39]}$ Milutinović M, Radulović Ž, Tomanović S, Tomanović Ž. Seasonal distribution of Borreliae in Ixodes ricinus ticks in the Belgrade region, Serbia. Arch Biol Sci. Belgrade, 2006; 58: 183-186.

${ }^{[40]}$ Hillyard PD. Ticks of North-West Europe. In: Kermack DM, Barnes RSK, Crothers JH (Eds) Synopses of the British Fauna (New Series). The Linnean Society of London and The Estuarine and Coastal Sciences Association, Shrewsbury, 1996.
${ }^{[41]}$ Diuk-Wasser MA, Hoen AG, Cislo P, et al. Human risk of infection with Borrelia burgdorferi, the Lyme disease agent, in eastern United States. Am J Trop Med Hyg. 2012; 8: 320-327.

${ }^{[42]}$ Mierzejewska J, Welc-Faleciak R, Karbowiak G, Kowalec M, Behnke JM, Bajer A. Dominance of Dermacentor reticulatus over Ixodes ricinus (Ixodidae) on livestock, companion animals and wild ruminants in eastern and central Poland. Exp Appl Acarol. 2015; 66:83-101.

${ }^{[43]}$ Del Fabbro S. Fencing and mowing as effective methods for reducing tick abundance on very small, infested plots. Ticks Tick Borne Dis. 2015; 6: 167-172.

${ }^{[44]}$ Gray JS. The development and seasonal activity of the tick $I x$ odes ricinus, a vector of Lyme borreliosis. Rev Med Vet Entomol. 1991; 79, 323-339.

${ }^{[45]}$ Gray JS, Dautel H, Estrada-Pẽna A, Kahl O, Lindgren E. Effects of Climate Change on Ticks and Tick-Borne Diseases in Europe. Interdiscip Perspect Infect Dis. 2009;2009:593232.

${ }^{[46]}$ CMHS 2019: Croatian Meteorological and Hydrological Service http://meteo.hr/klima.php?section=klima_pracenje\&par$\mathrm{am}=$ ocjena, accessed on March 24. 2019.

${ }^{[47]}$ Ploj M. Occurrence of ticks (Acarina: Ixodidae) and their development in Prekmurje (Lendavsko Dolinsko). Graduation thesis, University of Ljubljana, Ljubljana, Slovenia, 2007.

${ }^{[48]}$ Mikačić D. Ticks in the littoral belt of Yugoslavia III. Distribution and dynamics of species in the course of the year. Vet. arhiv, 1965; 35: 155-170.

${ }^{[49]}$ Estrada-Peña A, Venzal JM. Changes in habitat suitability for the tick Ixodes ricinus (Acari: Ixodidae) in Europe (19001999). EcoHealth, 2006; 3: 154-162

${ }^{[50]}$ Danielová V, Rudenko N, Daniel M, et al. Extension of Ixodes ricinus ticks and agents of tick-borne diseases to mountain areas in the Czech Republic, Int J Med Microbiol. 2006; 296 S1: 48-53.

${ }^{[51]}$ Beugnet F, Chalvet-Monfray K. Impact of climate change in the epidemiology of vector borne diseases in domestic carnivores. Comp Immunol Microbiol Infect Dis. 2013; 36: 559- 566.

${ }^{[52]}$ Hrklová G, Nováková M, Chytra M, Kostová C, Petko B. Monitoring and distribution and abundance of Ixodes ricinus ticks in relevance of climate change and prevalence of Borrelia burgdorferi sensu lato in northern Slovakia (Liptovská valley). Folia Vet. 2008; 52, 2: 62-63

${ }^{\text {[53] }}$ Punda-Polić V, Petrovec M, Trilar T, et al. Detection and identification of spotted fever group Rickettsiae in ticks collected in southern Croatia. Exp Appl Acarol. 2002; 28: 169-167.

${ }^{[55]}$ Lindström A, Jaenson TGT. Distribution of the common tick Ixodes ricinus (Acari: Ixodidae) in different vegetation types in Southern Sweden. J Med Entomol. 2003; 40: 375-378.

${ }^{[55]}$ Jongejan F, Uilenberg G. The global importance of ticks. Parasitology, 2004; 129: 3-14. 